\title{
BRINGING THE REAL WORLD OF SCIENCE TO CHILDREN: A PARTNERSHIP OF THE AMERICAN MUSEUM OF NATURAL HISTORY AND THE CITY UNIVERSITY OF NEW YORK
}

\author{
Anthony G. Picciano \\ Professor, Hunter College and Graduate Center \\ City University of New York
}

\author{
Robert V. Steiner \\ Project Director, Seminars on Science \\ National Center for Science Literacy, Education and Technology \\ American Museum of Natural History
}

\begin{abstract}
Every child has a right to an education. In the United States, the issue is not necessarily about access to a school but access to a quality education. With strict compulsory education laws, more than 50 million students enrolled in primary and secondary schools, and billions of dollars spent annually on public and private education, American children surely have access to buildings and classrooms. However, because of a complex and competitive system of shared policymaking among national, state, and local governments, not all schools are created equal nor are equal education opportunities available for the poor, minorities, and underprivileged. One manifestation of this inequity is the lack of qualified teachers in many urban and rural schools to teach certain subjects such as science, mathematics, and technology. The purpose of this article is to describe a partnership model between two major institutions (The American Museum of Natural History and The City University of New York) and the program designed to improve the way teachers are trained and children are taught and introduced to the world of science. These two institutions have partnered on various projects over the years to expand educational opportunity especially in the teaching of science. One of the more successful projects is Seminars on Science (SoS), an online teacher education and professional development program, that connects teachers across the United States and around the world to cutting-edge research and provides them with powerful classroom resources. This article provides the institutional perspectives, the challenges and the strategies that fostered this partnership.
\end{abstract}

\section{KEYWORDS}

Science Education, Teacher Education, Pre-Service, In-Service, Teacher Shortage, Distance Learning, Online Learning, Blended Learning, Multimedia

In this article, several abbreviations are used specifically:

- AMNH-American Museum of Natural History

- SoS-Seminars on Science

- CUNY-City University of New York
- SPS-School of Professional Studies (CUNY)

- NSU-Nova Southeastern University

- IB-International Baccalaureate 


\section{INTRODUCTION}

Every child has a right to an education. In the United States, the issue is not necessarily about access to a school but access to a quality education. With strict compulsory education laws, more than 50 million students enrolled in primary and secondary schools, and billions of dollars spent annually on public and private education, American children surely have access to buildings and classrooms. However, because of a complex and competitive system of shared policymaking among national, state, and local governments, not all schools are created equal nor are equal education opportunities available for the poor, minorities, and underprivileged. Children in well-funded schools in "better" neighborhoods of urban centers and higher-property taxed suburbs have greater access to a quality education than do children from the poorer inner cities and impoverished rural communities. One manifestation of this inequity is the lack of qualified teachers to teach certain subjects such as science and mathematics in many urban and rural schools. Even where certified teachers are available, laboratory facilities are ill-equipped to provide genuine, real-world science experiences that might be exciting for students and teachers alike. The purpose of this article is to describe a partnership model between two major institutions and the program designed to improve the way teachers are trained and children are ultimately taught and introduced to the world of science.

The American Museum of Natural History (AMNH) founded in 1869, located in New York City, is one of the great scientific and cultural institutions of the world. The City University of New York (CUNY), founded in 1847, is the largest urban university in the United States, enrolling more than 450,000 students in all of its programs. These two institutions have partnered on various projects over the years to expand educational opportunity especially in the teaching of science. While the two institutions have partnered on many face-to-face professional development projects over the past ten years, few have had the global potential for expanding educational opportunity for the teaching of science as Seminars on Science (SoS), the Museum's online teacher education and professional development program that connects teachers across the United States and around the world to cutting-edge research and provides them with powerful classroom resources. Opening up the AMNH treasure trove of science materials via media-rich online instruction, the real world of science is put at the fingertips of teachers in every school regardless of location or wealth.

In this article, the institutional perspectives, the challenges, and strategies that inform partnerships ranging from the local/regional levels to the world international community are explored. AMNH currently partners with nine institutions, including the International Baccalaureate Organization, to offer its program of online science courses. The opportunity to leverage freely available digital resources created by content-rich institutions such as AMNH and CUNY is also discussed, as is the opportunity to create blended learning experiences customized to the needs of local learners. Quantitative as well as qualitative evaluation data on the $S o S$, accumulated over a decade, is presented-focusing on the ways in which online professional development can improve scientific understanding and the understanding of the process of scientific inquiry as well as provide effective resources for teaching and learning. The voices of classroom teachers who have enrolled in $S o S$ courses and used its materials are also heard. Attention is paid to the policy and certification issues at many levels of governance that were overcome in order for this partnership to succeed, spurring similar partnerships with other educational institutions around the world. Finally, the online mode of delivering instruction using modern multimedia is highlighted as critical to the program's effectiveness and scalability. 
Bringing the Real World of Science to Children: A Partnership of the American Museum of Natural History and the City University of New York

\section{SCIENCE EDUCATION IN THE UNITED STATES}

A recent United Nations Educational, Scientific, and Cultural Organization (UNESCO) report [1] indicates that schools around the world will be facing a shortage of 18 million teachers within nine years unless governments invest more in public education. By 2015, the world will be short 13 million in the low income countries, and five million in the industrial economies. It has been well-documented that for much of the past decade, the United States has been experiencing a shortage of fully-certified, qualified teachers in its K-12 system. Estimates indicate that the country needs to hire as many as 1-2 million more certified teachers to fill vacancies in its teacher corps [2]. The issue is complicated by the fact that teachers are not necessarily unavailable in classrooms but that many teachers are not qualified to teach the courses to which they have been assigned. A major requirement of the No Child Left Behind Act (2002) - the major education funding program of the U.S. government-is that school districts recognize this issue and take corrective action to guarantee that every classroom is staffed by a fully-certified, qualified teacher. Legislation and action do not always coincide. Five years after No Child Left Behind (NCLB), the United States is still facing a shortage of qualified teachers. Ingersoll [3] makes the case that the issue is not that schools of education are not graduating enough teachers in their programs but that the number of teachers leaving the profession each year is equal to and in some areas, greater than the number of new teachers entering it. In 1999-2000, for example, 534,861 new teachers were hired in the U.S., while 539,778 teachers left the profession [3] for other employment or retirement. What this indicates is that of the 3,451,000 teachers in the workforce, approximately one-third or one million teachers are in transition either entering or leaving the profession each year. The problem is exacerbated by the growing population in the United States; with more children attending school, the need for more teachers also increases.

One critical aspect of the teacher attrition/shortage issue is its uneven distribution among types of schools, teacher abilities, and subject areas. The attrition tends to be greater in high-poverty, urban schools than in wealthier suburban schools [3]. Ingersoll and Perda estimated that the attrition in low-poverty, suburban public schools is $11 \%$ annually while urban, high-poverty public schools have more than double that rate [6, p. 9]. Several studies also indicate that teachers with higher ability, as measured by indicators such as the SAT, the National Teacher Exam, and teacher licensure tests, are more likely to leave the profession $[4,5]$. Most importantly, with regard to the subject at hand, the highest shortages of teachers are in mathematics, science and special education [6]. According to federal statistics, at the high school level, $61 \%$ of students who take chemistry and $45 \%$ who take biology are taught by teachers with neither a major nor certification in that subject [10]. All three of these factors-types of schools, teacher abilities, and subject areas-have a direct bearing on the quality of science education in the United States, especially in under-funded urban and rural schools.

The teaching of science is further complicated because of its dependence on special facilities, laboratories, equipment, and supplies. In a national study, one of the first of its kind of high school facilities, the National Research Council, concluded that:

...schools with higher concentrations of poor students are less likely to have adequate laboratory facilities than other schools. In addition to less adequate laboratory space, schools with higher concentrations of poor or minority students and rural schools often have lower budgets for laboratory equipment and supplies than other schools.

[As a result]...poor and minority students spend less time in laboratory instruction than students in other schools [7, p. 8].

The overall result of the lack of qualified teachers of science coupled with inadequate facilities is that science education in the United States is not what it should be in many schools. During the 30 years 
between 1969 and 1999, high school students' scores on the science portion of the National Assessment of Educational Progress "showed very little improvement". In addition, high school students' performance on a NAEP national science assessment, first administered in 1996, were lower four years later in 2000 [7, p. 1]. In its most recent assessment of science education, the U.S. Department of Education concluded that:

The results for NAEP science assessments reveal little improvement. Scores for fourth-graders have improved slightly over the past decade, but have remained flat for eighth-graders and declined for 12th-graders. In the fourth and eighth grades, only 29 percent of students scored at the "proficient" level or higher in 2005, declining to 18 percent for 12th-graders. As in mathematics, there are significant gaps between the scores of black and Hispanic students and those of white students [9, p. 6].

In high-poverty rural and urban schools, test results are generally lower than the national figures referenced above. In many smaller rural high schools, students are not able to enroll in science classes. Furthermore, it was estimated that these students were less likely (6.8\% versus $26.5 \%$ ) to take advanced placement science courses than students in central cities and in suburban fringe areas because of a lack of teachers and resources [8]. In a recent study of the results of student performance in ten urban school districts, their scores on the 2005 NAEP science assessment were uniformly lower when compared with national averages [10].

To address this issue, new programs in science education designed to prepare teachers as well as to improve the skills of existing teachers of science, many of whom are not certified in their subject area, are needed. State education departments responsible for developing certification standards, schools of education that prepare science educators, and school district recruitment and professional development programs need to consider approaches that are beyond the traditional. Programs need to be developed that expand the pedagogical and content expertise of teachers and make available resources that extend modern science into primary and secondary school classrooms. Many organizations including schools of education are attempting to do this through alternative certification programs. However, such programs meet resistance at many levels. State certification procedures have opened up small windows of opportunity but alternative certification is still viewed with suspicion and caution. Colleges and universities likewise favor traditional programs and have been slow to develop quality alternative programs. School districts especially in high-poverty areas continue to struggle to put qualified teachers in their classrooms and while some have embraced alternative certification programs; some of dubious quality have met with only marginal success. New approaches are needed, such as the $S o S$ that address multiple issues such as: teacher certification, pre-service and in-service training and development, and access to facilities and materials.

\section{SEMINARS ON SCIENCE: DESCRIPTION OF THE MODEL}

Seminars on Science (SoS), the online teacher professional development program of the American Museum of Natural History, was originally created as part of the Museum's strategy to leverage its scientific and educational infrastructure in order to help address the crisis in science education in the United States; it is now being extended to include teacher participants on an international basis. This crisis, both in the United States and around the world, centers on the need to prepare, retain and sustain enough qualified science teachers to ensure an adequate science, technology, engineering and mathematics (STEM) workforce as well as a scientifically literate public that can knowledgeably grapple with issues such as infectious disease, climate change and genetic engineering $[11,12,13,14]$.

Since its founding in 1869, AMNH has pursued a twin mission of science and education. It is renowned 
for its exhibitions and vast collections. Museum resources include collections of 32 million specimens and cultural artifacts, more than 100 annual expeditions, a library with more than two million items, and 42 exhibition halls. More than 200 active AMNH scientists conduct research, field work, and graduate and undergraduate training in fields as diverse as zoology, anthropology, paleontology, geo-science and astrophysics.

SoS was initially developed in order to connect contemporary research by scientists to both current and future teachers across the United States (some of its more recent international efforts are discussed below). Begun in 1998 and supported by two consecutive grants from The Atlantic Philanthropies, the program has broken new ground in the leveraging of museum-based expertise and resources for scientific research and education through online education to support professional development for science educators. The courses are designed to increase understanding of science, the process of scientific inquiry and the social, political and technological implications of scientific research. In the process, participating teachers create unit plans and acquire digital resources for classroom use.

The course model underlying SoS is based upon the application of research on teacher professional development in the sciences and integrates in one educational experience several successful strategies, including building understanding around a series of essential questions; connecting teachers with scientists and authentic scientific research; treating teachers as adult learners; emphasizing both scientific understanding and the process of scientific inquiry; engaging in an interactive process of design, development, field testing, evaluation and revision; and providing teachers with classroom resources [15, $16,17,18,19,20,21]$.

SoS currently includes ten online courses in the life, earth and physical sciences, each with a focus on contemporary scientific research. Each semester-equivalent course is six weeks in duration and provides flexible access to both pre-service and in-service teachers across the United States and around the world. While the focus of each course is on content knowledge, course projects, digital resources (including a resource $\mathrm{CD}$ ) and discussion forums all provide a strong connection to classroom practice. Each of the courses is the result of a collaboration between one or more AMNH scientists and the educators, professional developers and educational technologists who comprise the Museum's National Center for Science Literacy, Education and Technology. The course media include original essays, images and video derived from the Museum's scientific and educational resources, its exhibitions and its laboratories, as well as other web-based materials.

Each course is taught by an experienced classroom educator (who has been prepared to teach in an online environment) as well as by a scientist (who may or may not be an authoring scientist of the course). Through a set of higher education partnerships, course participants have the option of enrolling for three or four graduate credits. The content for each course is correlated to the National Science Education Standards, a set of guidelines for science education in primary and secondary schools in the United States. In addition, each course has been developed in accord with the science teaching standards of the National Board of Professional Teaching Standards.

The program is supported by a course management system (eCollege) that provides for easy navigability to course content, discussions, assignments and linked resources while also providing a range of tools for academic, administrative and 24/7 technical support.

The course titled Evolution, for example, draws on AMNH's long-standing leadership in the fields of paleontology, geology, systematics, and molecular biology to tell a modern story of evolution. Students will learn why evolution is the fundamental concept that underlies all life sciences and how it contributes to advances in medicine, public health and conservation. Each week's activities include theme questions, 
essays, interviews with scientists, and multimedia materials such as text, animation, and video designed to teach and to stimulate interest in the topic. Weekly essential questions include: "What is the evidence for evolution?"; "What are the mechanisms of evolution?”; "How did humans evolve?" and "What are modern applications of evolutionary theory?" The course is co-authored by and includes interviews with Niles Eldredge, a curator in the Division of Paleontology, and Joel Cracraft, a curator in the Department of Ornithology, both of whom are internationally recognized experts in their fields. Participants learn first-hand of the theory of punctuated equilibrium of Eldredge and the late Stephen Jay Gould, learning of Eldredge's unique perspective on both the science and the process of scientific discovery. Other essays, including several by guest scientists, speak to a range of topics including whale evolution, the history of bird populations, co-evolution of species, the tracking of the grey moth, the emergence of the human species and the tracing of emerging influenza strains. Weekly assignments include the creation of a phylogenetic tree as well as the final project, typically a curricular unit, that is common to all SoS courses. The "Meet the Relatives" interactive animation allows participants to compare human structure and function with that of a chimpanzee and a Neanderthal-our closest living and extinct relatives. A host of video resources designed to provide powerful sights and sounds for delving more into evolution's paths are provided on a CD-ROM. The new (2006) AMNH exhibition website on Charles Darwin (http://www.amnh.org/exhibitions/darwin/) is a major resource wherein the voyage of The Beagle is presented in essays, video and audio materials. In sum, this course exemplifies ways in which the Museum's "treasure trove" of content can be re-purposed for and integrated into provocative, educational activities. The approaches described above are critical to SoS's effectiveness and scalability because teaching and learning science is about seeing, hearing, and feeling things as well as reading about them. Providing experiences that bring the learner closer to actual events, phenomena, and people makes the subject come alive. It would be impossible for individual teachers or schools to duplicate the rich multimedia materials, derived from a century and a half of science knowledge accumulated by the AMNH, that form the fabric of each SoS seminar.

SoS has evolved over three fairly discrete phases: Phase I (1998-2002) focused on the design, development, evaluation and revising of the course model. Course titles included Genetics, Genomics, Genethics; Earth: Inside and Out; From Dinosaurs to Birds; The Study of Spiders; Sharks and Rays; and Life in the Universe. Phase II (2002-2006) focused on the research, development and evaluation of pilot partnerships between $S o S$ and other entities within the framework in which professional development takes place in the United States. These entities include higher education institutions, school districts, regional educational agencies and other informal science institutions. This phase also saw the development of a financial plan and the development of new courses titled Space, Time and Motion and The Ocean System as well as an instructor preparation course ("Teaching Science Online"). Phase III (2006- ) is a period devoted to achieving scale and sustainability while also exploring new opportunities in blended education, in course licensing and in international partnerships and collaborations. It has also seen, thus far, the creation of two additional courses: Evolution and The Solar System.

\section{EVALUATION OF THE MODEL}

In 1999, the American Museum of Natural History commissioned Inverness Research Associates (Inverness, California) to conduct an independent evaluation of the SoS. The first evaluation during the initial phase (1999-2002) of the project was conducted with a number of recommendations for revision and refinement [22]. A final report was completed by Inverness in 2006 [23]. Quantitative and qualitative data were collected from participants via annual surveys and in-depth interviews conducted over a sixyear period (1999-2005). Some of the key findings from these studies are presented below.

During the six-year period of the evaluation, participants $(\mathrm{N}=1,789)$ in $S o S$ courses came from 44 states 
and Washington DC, as well as Canada and Singapore. Participants were from rural, suburban, and urban areas. Seventy-seven percent of participants were teachers, of whom about $70 \%$ taught science at the middle or high school levels. Participants who were not teachers included museum educators, librarians, and technology educators [23, p. 3].

In response to survey questions conducted approximately six months after completing their courses, the majority of teacher participants reported that SoS provided significant benefits to them as educators. Results from this these follow-up surveys of teacher participants are summarized below:

\begin{tabular}{|l|c|}
\hline Benefits to teachers & $\begin{array}{c}\% \text { agree or } \\
\text { strongly agree }\end{array}$ \\
\hline Enhanced my content knowledge in a subject area I teach regularly & $61 \%$ \\
\hline Helped me to learn a new content area that I may teach in the future & $60 \%$ \\
\hline Provided a bank of resources that I can share with my students & $68 \%$ \\
\hline $\begin{array}{l}\text { Introduced me to new kinds of materials and media I can use in } \\
\text { science (e.g. simulations, websites) }\end{array}$ & $67 \%$ \\
\hline $\begin{array}{l}\text { Provided me with hands-on, inquiry learning experiences that can } \\
\text { serve as a good model for the kind of work I can have students do }\end{array}$ & $55 \%$ \\
\hline
\end{tabular}

Source: Inverness Research Associates [23, p. 14]

The majority of teacher participants also indicated that SoS course experiences resulted in significant benefits to their students as follows:

\begin{tabular}{|l|c|}
\hline Benefits to students in my classroom & $\begin{array}{c}\text { \% agree or } \\
\text { strongly agree }\end{array}$ \\
\hline Helped students connect science in school to the real world & $60 \%$ \\
\hline Made the work of scientists more understandable to students & $52 \%$ \\
\hline Increased students' understanding of scientific inquiry & $50 \%$ \\
\hline Increased students' access to and knowledge of latest research & $55 \%$ \\
\hline
\end{tabular}

Source: Inverness Research Associates [23, p. 18]

One of the significant benefits for the participants was the use of SoS course materials (e.g., course CDs) in their own classes. Below are examples of quotes (voices) from middle and high school teaches regarding SoS course materials:

"I was able to use 75\% of the stuff... It made me aware of resources I didn't know existed."

"I have used most of the resources from the SoS courses in both my vertebrate zoology and human anatomy \& physiology classes. I have also used both of my final projects in part or in entirety during the last marking period of this school year." 
"I am currently teaching paleontology. I have been able to share the CD I received with my students and have used info from the web sites used during the course. I have also used the essays as readings for my students. The lesson plans I developed are being used this semester” [23, pp. 16-17].

In addition, the availability of world class scientists in the online environment also added significantly to SoS course experiences for participants. For example:

"The scientists involved are extraordinary, and they are from all over the world. It is incredibly rich.”

“...the scientists' weekly lectures were written with great clarity. Skillful weaving of descriptions and analogies into the discussion make the content accessible even to someone with limited prior knowledge of the topic."

"The scientist was so very positive in what she did, even when you were off mark. As adults, we don't want to make mistakes and in each course there was something I just didn't understand" [23, p. 13].

The online nature of these courses also provided opportunities for participants who follow busy if not hectic schedules in their daily lives. One teacher indicated that:

"I have taken a number of grad courses and I really like these. They go with my lifestyle - on line, get a week to post answers. I have two small kids and am a single mom. A lot of work but I could manage it within my own time frame and that was important to me [23, p. 13].

The Inverness evaluators concluded that "SoS stands out as a new kind of professional development resource that is providing an important service for science education." SoS allows teachers throughout the world who normally cannot personally visit the exhibits and resources of the AMNH to experience some of its treasures via online technology. Furthermore, it integrates access to these materials with the chance to interact with world-class scientists who are able to inspire and stimulate the pedagogical thinking of teachers seeking to provide worthwhile instruction for their students. The need for accessible networked educational technologies to facilitate this professional development opportunity-as well as other similar kinds of opportunities that can connect students and their teachers to vast scientific and educational resources-is inextricably intertwined with the right to an education, suitably updated to the $21^{\text {st }}$ century [23, p. 1].

\section{THE ROLE OF PARTNERSHIPS AND COLLABORATIONS}

AMNH enters into partnerships and collaborations with colleges, universities, informal science institutions, school districts, local educational agencies, and science teacher associations at the local, regional, national and international level in order to leverage synergies that can ultimately improve the education and professional development of teachers of science. Higher education partners typically offer graduate credit for their courses, sometimes partner with the museum in seeking external funding for research in online and blended science education and, along with the other kinds of entities listed, help to disseminate the program to potential participants. In partnering with $\mathrm{AMNH}$, these organizations are able to help facilitate the connection of their learners to working scientists, content knowledge on cutting-edge research, and classroom resources. 
As described earlier, the first four years of $S o S$ were dedicated to the research, design, development, implementation, evaluation and improvement of the course model in an iterative approach to educational innovation. During this time, the course model was developed and field-tested on several hundred teachers across the United States. With strong support for the idea that AMNH could develop and support online courses that teachers found to be accessible, innovative and effective, it then became a primary challenge to understand where these courses might best be situated within the complex framework within which teacher professional development takes place in the United States. Consideration as to what constitutes an appropriate and desirable partnership involves multiple factors, but primary among these are the opportunities for achieving scale (the number of program participants), impact (the effect upon the participants) and sustainability (the ability to provide financial and organizational support for the program on a continuing basis).

Within the United States, the teacher professional development framework includes traditional, online, and blended courses, workshops, and field experiences offered by higher education institutions, school districts and other organizations-both for-profit and not-for-profit-involved with $\mathrm{K}-12$ teacher professional development.

The development of partnerships began in earnest with the convening of a three-day conference at AMNH to potential partnering organizations. Those invited to attend included colleges and universities (e.g. City University of New York, Western Governors University), school districts (Tucson [Arizona] Unified School District), regional educational entities (Eastern Suffolk [Long Island, New York] Board of Cooperative Educational Services), and other informal science institutions (Fort Worth Museum of Science and History, and the Exploratorium (San Francisco, California). A representative of AMNH's course management system [eCollege] attended the conference as well. The details of the evolution of the partnerships with each of these organizations are idiosyncratic and beyond the scope of this paper. Partnership discussions typically required an understanding on the part of AMNH of institutional needs and resources, of institutional processes, contexts and constraints. Recurrent issues included (but were certainly not limited to) financial arrangements, academic approval, course staffing, registration, program promotion, course/instructor evaluation and transcript processing. Ultimately, some of these discussions resulted in partnerships with formal memoranda of understanding, such as the one between AMNH and CUNY, that have evolved and continue to flourish; others resulted in pilot partnerships that, for a variety of reasons (including, for example, financial constraints, institutional priority and staff support) did not go beyond a pilot stage. And some institutions, while expressing interest in $S o S$, ultimately decided not to pursue even a pilot program.

\section{A. The AMNH-CUNY Partnership For Online Teacher Education}

AMNH and CUNY have a long history of partnership and collaboration. AMNH scientists have served as adjunct faculty in the science departments at CUNY and a number of CUNY scientists are formally affiliated with the Museum utilizing its laboratories and resources. The AMNH Education Department and CUNY faculty have also long collaborated offering a broad array of courses, workshops, and institutes mainly for New York City teachers who form a natural local base for such programs.

In Spring 2003, CUNY announced the creation of the School of Professional Studies (SPS), a new school of the university with a mission to create professional development and lifelong learning programs that could be offered on a university-wide basis. The focus was on creating programs that were innovative, accessible, and academically rigorous. From its inception, SPS envisioned programs that could be offered face-to-face, online, or as a blended combination. The ability of SoS courses to fulfill the science content needs of pre-service and in-service teachers, the ability of SPS to offer educational programs that spanned 
the individual CUNY campuses, and the strong preexisting relationship between AMNH and CUNY led to a formal agreement to offer SoS courses to CUNY students for graduate credit.

The original agreement provided that, subject to approval by the SPS, each SoS course would be made available to graduate students in teacher education programs; that courses would be restricted to matriculated CUNY students; and that course instructors would be appointed as adjunct CUNY instructors. Processes for registration, student evaluation, program dissemination, and other matters were developed and later refined over time. Particular attention was paid to compliance with both AMNH and CUNY SPS institutional policies as well as federal and state policies governing higher education course and program offerings.

What is most interesting about this partnership is its engagement with the CUNY School of Professional Studies rather than one of the traditional CUNY colleges. College governance issues related to curriculum approval, faculty hiring and review, and revenue sharing would have made it difficult for one of the traditional CUNY colleges to partner with AMNH for SoS courses. SPS, on the other hand, was specifically created to develop and offer non-traditional, innovative programs aimed primarily at the professional development of working adults. Its governance structure and administrative procedures are streamlined compared to the traditional CUNY colleges and designed to be flexible in developing programs including those that require partnering with other entities such as businesses, collective bargaining organizations, or cultural institutions such as AMNH. The ability of both Seminars on Science and SPS to move nimbly and flexibly, the trust engendered by the longstanding relationship between AMNH and the CUNY and the collective knowledge, skills and experience among leadership and staff in both organizations of the intersecting worlds of higher education, science education, teacher professional development and online education all were central to the ultimate success of this partnership.

\section{B. Partnerships Expand}

The partnership between AMNH's SoS and CUNY raised a number of issues, several of which are discussed in detail in the following section. While posing its own unique challenges and opportunities, this partnership was an important starting point as AMNH subsequently sought to develop partnerships with other organizations. Currently AMNH SoS has formal partnership agreements with nine entities and informal collaborations with a number of others ${ }^{1}$. These entities differ markedly in their missions, their reach, and their internal organization, but they have in common a dedication to improving the understanding of science among students, teachers and the general public.

Due to limitations in the scope of this paper, this section will restrict its focus to two of these partnering institutions. One of these-Nova Southeastern University-is a university with a large online presence that provides a multitude of educational offerings on both a national and international basis. The otherthe International Baccalaureate Organization-is a nonprofit K-12 organization seeking to enhance its science professional development offerings to support the distinctive curriculum it makes available to schools on an international basis.

Nova Southeastern University (NSU) is a coeducational, independent, non-profit university with its main campus in Davie, Florida and an enrollment of 26,000 students. It is the sixth largest independent

1 The current list of formal partnerships and collaborations includes Adams State College, Bank Street College of Education, the City University of New York (School of Professional Studies), Hamline University, the International Baccalaureate Organization, the National Science Teachers Association, Nova Southeastern University, Plymouth State University and Western Governors University. 
institution of higher education in the United States. The university operates programs in Florida and at its sites in 23 states in the USA and in 14 foreign countries.

The partnership agreement between AMNH and Nova Southeastern University's Fischler School of Education and Human Services was completed in 2005. The partnership provides AMNH with both domestic and international opportunities for program dissemination, while NSU is able to provide additional choices in science education to both matriculated and non-matriculated students (and potentially attract some of the latter into its degree programs). Up to three SoS courses can be used by graduate (Masters of Science) students in science education toward the fulfillment of degree requirements. In 2007, NSU received external funding from the Florida Department of Education to support the professional development of science teachers in the Manatee County area of Florida. Through this funding, a further influx of teachers into SoS courses is expected over the coming year.

In 2007, AMNH and the International Baccalaureate Organization (IB) entered into a partnership that differs considerably from the CUNY and NSU higher education partnerships described above. IB is a non-profit organization that offers three challenging educational programs through a pre-kindergarten through grade twelve curriculum framework for a worldwide community of schools, along with corresponding instructional strategies, assessment rubrics, and IB-certified teacher professional development. This professional development is provided either through IB staff or through IB-approved contracted providers. Through this partnership, SoS courses will become available as IB-recognized professional development to IB teachers on a global basis, including the Primary Years Programme (PYP) for students ages 3-12, Middle Years Programme (MYP) for students from ages 11-16, and the Diploma Programme (DP)for students ages 16-19).

As part of the partnership agreement, the course experience for IB teachers has been tailored to meet their particular needs. The summative project for such teachers is consistent with the IB curriculum framework and is assessed according to a special rubric. In addition, a discussion forum has been added, led by a member of the IB professional development staff, that allows for a more direct connection between the science discussed and the IB classroom application. Finally, IB and AMNH have both benefited from the participation of several IB teachers as members of the $S o S$ instructional staff.

With the AMNH-IB partnership only recently announced, the number of participating teachers is still small. However, it is expected to grow steadily as the partnership is promoted in IB-affiliated print, electronic, and conference/workshop venues. Together, IB and AMNH will reach out to international schools and other IB-affiliated supporting organizations in order to make the courses available to the largest possible number of teachers.

As the number of partnerships grows, it is becoming clear that multiple partnerships are evolving that can offer synergistic opportunities that transcend those of the individual partnerships. For example, AMNH and NSU are also actively pursuing the development of programs that will offer NSU courses, certificate and/or degree programs to cohort groups on an international basis. Many of these participants are likely to include teachers working in IB-affiliated schools. With IB, NSU and perhaps other partners, the courses can be offered as part of graduate certificate or degree programs and perhaps adding a face-to-face component that could include teaching methods and/or additional science content. Such a collaboration, leveraging diverse strengths and far-flung staff, provides for a capability that would be difficult for an individual institution to attain in isolation. 


\section{Issues and Lessons Learned}

The Seminars on Science experience underscores for us the opportunities for educational access and pedagogical innovation that can arise when a higher education provider partners with an institution that, at least in part, constitutes a "treasure trove" content repository. In addition to museums, other such repositories exist in other informal science institutions as well as in the archives of public television and public radio as well as in print and electronic media (whether publicly held or not). The complementarities of institutional strengths carry the potential to provide a more powerful educational experience than either institution alone might be able to offer, and may therefore be better poised to reach more teachers.

In any partnership or collaboration, issues arise that require careful consideration and negotiation. The initial partnering with CUNY provided AMNH staff with important experiences and insights into these issues as they sought to negotiate partnerships with other colleges and universities. These issues can be categorized as follows:

- Basic operational and logistical issues involving registration, grading, transcript processing, course articulation, and marketing. While time-consuming, many of these were resolvable once the decision was made by senior administrators to move forward with a partnership.

- Technological issues mostly involving the course management system (CMS) and the need for providing student technical support. Colleges and universities with their own CMS were concerned about supporting and requiring students to learn the eCollege template used by SoS.

- Financial issues associated with tuition, fees, and revenue sharing. These were more serious for publicly-funded institutions most of whom are subject to state or local fiduciary regulations and guidelines. For instance, the setting of student tuition and fees typically is not the prerogative of local public colleges but need to be approved by larger governing bodies. Many states and localities also have well-established revenue sharing policies in place that do not easily provide for sharing with outside entities.

- Perhaps of primary importance, there were a number of cultural, political, and policy issues related to the fact that an outside entity such as AMNH had developed and would be the main provider of a specific set of courses. This created a number of issues involving the evaluation and approval of $S o S$ courses by faculty governing bodies, union concerns regarding compensation for AMNH faculty and instructors, and competition with the college's own academic programs. These proved difficult to resolve and in some cases were major obstacles to moving forward with a partnership.

It is widely understood that partnerships are challenging, and that partnerships involving higher education institutions are particularly vulnerable to issues of academic quality, financial viability, institutional policy, ownership and control concerns, and long-term sustainability. Resolution of such matters is aided by mutual familiarity and trust, generosity of spirit, the expertise and timely communication between key staff in each institution (e.g. institutional liaisons, marketing coordinators, those responsible for registration and transcript processing), as well as a deeper understanding of the mission, processes and traditions of the partner institutions.

A compatibility of institutional missions (e.g. knowledge creation, development of a scientifically literate citizenry) and philosophies strengthens the prospect of a successful partnership. AMNH, in partnering with higher education institutions, has worked hard to uphold the standards of academic quality, to respect the privacy of student identities and course communications, to continue its commitment to educational research and course and program evaluation, and to work with its partners in order to understand how best to evolve the SoS program. While traditionally a science institution, AMNH, as 
described in earlier sections, is inextricably intertwined with higher education and respects its policies and processes.

In order to grow fruitful partnerships, SoS has tried to minimize the partner burden with respect to program marketing and course operations. At the same time, higher education institutions understandably tended to maximize their sense of ownership and control over courses for which they granted academic credit, often hesitating to embrace offerings not created within their institution. Within the constraints needed to maintain its unique identity, $S o S$ has worked hard to involve its partners as deeply as possible by listening to partner feedback, customizing evaluations, cultivating instructors affiliated with partner institutions, and regularly creating customized discussion forums, summative projects, and evaluation rubrics to suit particular needs. These experiences may be useful in informing the vision, strategies and plans of other institutions considering similar collaborations.

\section{CONCLUSION}

This article is based on the concept that every child has a right to an education. While the article does not address the larger issue of providing a basic education to all children, it does address the specific issue of access to a quality science education lacking in the United States and many other countries. Given the shortage of trained and content-knowledgeable science teachers, this issue is a particular concern in underserved rural and inner city schools rather than suburban schools. Nevertheless, because of the ongoing explosion of knowledge in science and technology, the need for access to current thinking and practicing experts can be beneficial to teachers in all schools.

Seminars on Science is not a "silver bullet" that will resolve all of the issues related to science education but it can be an important part of the solution by providing a unique collaborative model for bringing the real world of science to public school teachers and in turn to their students. Given its newness and limited number of partnerships, SoS does not pretend to have resolved the significant shortage of science teachers that exists in the United States. However, if other scientific institutions (museums, research centers, zoos, botanical gardens) were to consider a similar approach, a major improvement in the way science is taught in this country and beyond might evolve. SoS provides the model in which the riches of its collections and personnel expertise are extended to the everyday teacher. By relating their instruction to that of world class science and scientists, it enables these teachers to go beyond the basic textbook and lesson plans and to awaken in their students to the sights, sounds and emotions of doing science. Furthermore, the partnership aspect of the SoS approach seeks to collaborate with those colleges and universities that are the major providers of teacher educators in this country. This approach holds the promise of extending the merits and benefits of the SoS program across many institutions potentially reaching thousands of teachers and hundreds of thousands of K-12 students.

Finally, the vision, strategy, and plan initially envisioned for partnerships will inevitably evolve over the course of time. In Seminars on Science, the dynamism of the collaborative online environment has already resulted in many initially unplanned activities such as cohorts of learners, non-matriculated extensions, blended offerings and the incorporation of the courses into certificate and degree programs. The program's integration of content with new and emerging online technologies, and new approaches to course design and development as well as program dissemination and evaluation all bear ongoing scrutiny. 


\section{ACKNOWLEDGEMENTS}

The authors of this paper would like to acknowledge the fine work and cooperation of the many educators, scientists and administrators of the American Museum of Natural History who have contributed to Seminars on Science, including, in particular, the staff of the Education Department and its National Center for Science Literacy, Education and Technology; to all Seminars of Science partners and to the many friends of the program; and to Mark St. John, Laura Stokes and their colleagues at Inverness Research Associates. At the Museum, we wish to acknowledge in particular the efforts of Lisa Gugenheim, Rosamond Kinzler, Maritza Macdonald, David Randle, J. K. Rasmussen and Armistead Booker as well as the past efforts of Myles Gordon, Nancy Hechinger, Francine Stern and John Yoo. We are also grateful to John Mogulescu, George Otte and Brian Peterson of the City University of New York; to Maria Hersey and Anthony Tait of International Baccalaureate North America; and to Anthony DeNapoli and Shelley Green at Nova Southeastern University for their review of this manuscript and their suggestions. Elaine Bowden also significantly helped in editing drafts of this manuscript. Seminars on Science gratefully acknowledges the generous financial support of the Sherman Fairchild Foundation as well as prior support from The Atlantic Philanthropies, the National Oceanic and Atmospheric Administration and the Educational Foundation of America.

\section{REFERENCES}

1. United Nations Radio. United Nations Educational, Scientific, and Cultural Organization (UNESCO) Warns of looming teacher shortage by 2015.

2. National Commission on Teaching and America's Future. Doing what matters most: Investing in quality teaching. New York: NCTAF, 1997.

3. Ingersoll. R. A. Is there really a teacher shortage. Philadelphia: A research report co-sponsored by The Consortium for Policy Research in Education and The Center for the Study of Teaching and Policy, September, 2003.

4. Stinebrickner, T. R. A dynamic model of teacher labor supply. Journal of Labor Economics 19(1): 196-230, 2001.

5. Henke, R., L. Zahn \& D. Carroll. Attrition of new teachers among recent college graduates. Washington, DC: National Center for Education Statistics, 2001.

6. Ingersoll, R. A. \& D. Perda. What the data tell us about shortages of mathematics and science teachers. Paper presented at the NCTAF Symposium on the Scope and Consequences of K12 Science and Mathematics Teacher Turnover, October, 2006.

7. Singer, S. R., M. L. Hilton \& H. A. Schweingruber (Eds.). America's Lab Report: Investigations in High School Science. National Academy of Science, National Research Council, 2005. http://www.nap.edu/catalog/11311.html, accessed June 10, 2007.

8. U.S. Department of Education, National Center for Education Statistics. The Condition of Education 2005, NCES 2005-094, Washington, DC: U.S. Government Printing Office.

9. U.S. Department of Education. Report of the Academic Competitiveness Council, Washington, D.C., 2007.

10. Cavanaugh, S. Urban students fold under basic science. Education Week 26(13): 5, 13, November 29, 2006.

11. Steiner, R, M. Macdonald, R. Kinzler and M. Gordon. Online Science Professional Development at the American Museum of Natural History. In C. Dede, Online Professional Development for Teachers, 137-154. Harvard Education Press, 2006.

12. National Academy of Sciences. Rising Above the Gathering Storm: Energizing and Employing America for a Brighter Economic Future. National Academies Press, 2006. 
13. U.S. Department of Education. Before It's Too Late: A Report to the Nation from the National Commission of Mathematics and Science Teaching for the $21^{\text {st }}$ Century, U.S. Department of Education, 2000.

14. Darling-Hammond, L. What Matters Most: Teaching for America's Future. National Commission on Teaching and America's Future, 1996.

15. Loucks-Horsley, S. Designing Effective Professional Development for Teachers of Science and Mathematics. National Institute for Science Education, 1998.

16. Falk, J. H. \& L. D. Dierking. The Museum Experience. Walnut Creek, CA: Alta Mira Press, 2000.

17. Hein, G. E. Learning in the Museum. London: Routledge, 1998.

18. National Board of Professional Teaching Standards. Early Adolescence/Science Standards for National Board Certification, 1997. http://www.nbpts.org/candidates/guide/whichcert /18EarlyAdolScience2004.html, accessed December 31, 2007.

19. Bransford, J. D., A. L. Brown \& R. R. Cocking. How People Learn: Brain, Mind, Experience and School. Washington, D.C.: National Academy Press, 2000.

20. National Research Council. National Science Education Standards. National Academy Press, 1996.

21. Shulman, L. S. Teacher development: Roles of domain expertise and pedagogical knowledge. Journal of Applied Developmental Psychology 21: 129-135, 2000.

22. St. John, M., L. Stokes \& J. Hirabayashi. The AMNH Seminars on Science Project: Lessons learned from Phase I 1999-2002. Inverness, CA: Inverness Research Associates, October 2002.

23. Stokes, L., M. St. John, J. Hirabayashi \& A. Smith. Results from the independent evaluation of the Seminars on Science. Inverness, CA: Inverness Research Associates, October 2006.

\section{ABOUT THE AUTHORS}

Anthony G. Picciano is a professor in the graduate program in Education Leadership at Hunter College. $\mathrm{He}$ is also a member of the faculty of the Ph.D. program in Urban Education and the program in Interactive Pedagogy and Technology at the Graduate Center of the City University of New York, and is on the consortial faculty of the interdisciplinary program in Communication and Culture at the CUNY School of Professional Studies. He has thirty-eight years of experience in education administration and teaching, and has been involved in a number of major grants from the U.S. Department of Education, the National Science Foundation, IBM, and the Alfred P. Sloan Foundation.

In 1998, Dr. Picciano co-founded CUNY Online, a multi-million dollar initiative funded by the Alfred P. Sloan Foundation that provides support services to faculty using the Internet for course development. Currently he serves on the Board of Directors of the Sloan Consortium. His major research interests are school leadership, education policy, Internet-based teaching and learning, and multimedia instructional models.

Dr. Picciano has authored numerous articles and eight books including Data-Driven Decision Making for Effective School Leadership (2006, Pearson), Educational Leadership and Planning for Technology, 4th Edition (2005, Pearson), Distance Learning: Making Connections across Virtual Space and Time (2001, Pearson), and Educational Research Primer (2004, Continuum). His most recent book was co-edited with Chuck Dziuban and is entitled, Blended Learning: Research Perspectives (2007, Sloan Consortium). Dr. Picciano also recently (February 2007) finished a national study, with Jeff Seaman on the extent and nature of online learning in American school districts. It is one of the first studies to collect data on and compare fully online and blended learning in K-12 schools. (http://www.sloan-c.org/publications /survey/K-12_06.asp).

Robert V. Steiner serves as the Project Director for Seminars on Science, the online professional 
development program of the American Museum of Natural History in New York City. The awardwinning program offers online courses in the life, earth and physical sciences to K-12 educators across the United States. Dr. Steiner is responsible for the leadership and management of all aspects of the program, including partnership creation, external funding, course development, faculty and learner support, cybercampus operations, marketing, and evaluation.

Prior to his work at the Museum, Dr. Steiner created and directed the Distance Learning Project at Columbia University's Teachers College. This pioneering effort resulted in the creation of over 60 online and hybrid graduate courses as well as certificate programs in technology education. The program provided faculty, students and administration with knowledge of both the theory and practice of webbased education.

Dr. Steiner received his B.S. in physics from the University of California, Berkeley and his Ph.D. in physics from Yale University. At Adelphi University he served as a faculty member within the Department of Physics and a principal investigator for the National Science Foundation in the area of experimental elementary particle physics. He has created computerized physics laboratories and chaired or served on numerous faculty committees related to technology and education and serves as a member of the adjunct faculty of the City University of New York's Queens College within its Department of Physics.

Dr. Steiner has served as a consultant in science education and has presented widely within the science education and online education communities. He lives in New York City with his wife and their two young children. 